\title{
Economic Evaluation of Solar-only and Hybrid Power Towers Using Molten Salt Technology
}

\author{
Gregory J. Kolb \\ Sun + Lab \\ CONF- $961016--2$ \\ Sandia National Laboratories \\ Albuquerque, NM, USA \\ RECEIVED
}

NOV 061996

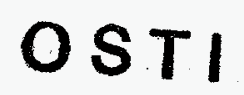

\begin{abstract}
Several hybrid and solar-only configurations for molten-salt power towers were evaluated with a simple economic model, appropriate for screening analysis. The solar specific aspects of these plants were highlighted. In general, hybrid power towers were shown to be economically superior to solar-only plants with the same field size. Furthermore, the power-booster hybrid approach was generally preferred over the fuel-saver hybrid approach. Using today's power tower technology, economic viability for the solar power-boost occurs at fuel costs in the neighborhood of $\$ 2.60 / M B t u$ to $\$ 4.40 /$ MBtu (low heating value) depending on whether coalbased or gas-turbine-based technology is being offset. The cost of $\mathrm{CO}_{2}$ avoidance was also calculated for solar cases in which the fossil fuel cost was too low for solar to be economically viable. The avoidance costs are competitive with other proposed methods of removing $\mathrm{CO}_{2}$ from fossil-fired power plants.
\end{abstract}

This work was supported by the United States Department of Energy under Contract DE-AC04-94AL85000.

Sandia is a multiprogram laboratory operated by Sandia Corporation, a Lockheed Martin Company, for the United States Denartment of Energv. 


\section{DISCLAMMER}

Portions of this document may be illegible in electronic image products. Images are produced from the best available original document. 


\section{DISCLAIMER}

This report was prepared as an account of work sponsored by an agency of the United States Government. Neither the United States Government nor any agency thereof, nor any of their employees, makes any warranty, express or implied, or assumes any legal liability or responsibility for the accuracy, completeness, or usefulness of any information, apparatus, product, or process disclosed, or represents that its use would not infringe privately owned rights. Reference herein to any specific commercial product, process, or service by trade name, trademark, manufacturer, or otherwise does not necessarily constitute or imply its endorsement, recommendation, or favoring by the United States Government or any agency thereof. The views and opinions of authors expressed herein do not necessarily state or reflect those of the United States Government or any agency thereof. 


\section{Introduction}

The solar power tower concept is characterized by a tower-mounted receiver that is cooled by molten salt. The receiver is heated by reflected energy from a field of sun-tracking mirrors, called heliostats. Figure 1 shows a flow schematic of this system. Molten salt at $550^{\circ} \mathrm{F}\left(288^{\circ} \mathrm{C}\right)$ is pumped out of a "cold" storage tank to the receiver where it is heated to $1050^{\circ} \mathrm{F}\left(565^{\circ} \mathrm{C}\right)$ and delivered to a "hot" storage tank. The hot salt is then extracted for generation of $1000^{\circ} \mathrm{F}\left(538^{\circ} \mathrm{C}\right)$ steam in the steam generator. The steam powers the turbine to produce electricity. Molten salt was chosen as the preferred heat transfer fluid because it has good heat-transfer properties; provides an efficient and low-cost thermal storage medium, and produces steam temperatures that are compatible with high efficiency Rankine-cycle turbines. Cost effective storage allows the power plant to achieve high annual plant load factors $(>60 \%)$ and to dispatch electricity to the grid when needed, even during cloudy weather or at night.

In 1996, an industry/government consortium led by Southern California Edison, completed startup of the Solar Two power plant. The purpose of this $10 \mathrm{MW}_{\mathrm{e}}$ plant is to demonstrate the practicality of molten salt power tower technology during a 3-year operating period [21]. Assuming success of Solar Two, it is currently envisaged that the initial commercial-scale plants will be deployed within the US Solar Enterprise Zone (southern Nevada) and within developing nations such as India, Egypt, and Mexico.

The first commercial plants will be significantly larger than Solar Two, capable of producing up to $100 \mathrm{MW}_{\mathrm{e}}$. A large monetary investment will be required to build these plants and, since the power tower is a new generation technology, the financial risk will be perceived to be high by potential investors. They will require a high rate of return to balance the risk which could drive up the cost of solar power beyond affordability. To reduce risk, the US solar thermal community is currently promoting a commercialization strategy in which the first power towers are hybridized with fossil fuels. By designing a hybrid plant in which 10 to $30 \%$ of the annual electricity is derived from solar energy, financial risk is minimized because the majority of the electricity is derived from proven fossil technology and steady payments for power sales is assured. Furthermore, as will be shown in this paper, hybridization also significantly reduces the cost of producing solar power.

With today's inexpensive fossil fuel, it is difficult for grid-connected solar plants to economically compete with fossil plants; hybridization will help close the gap. Eventually, as fossil fuel prices rise and more manufacturing experience is gained resulting in a cost reduction for solar equipment, large solar-only plants in the 200 to $400 \mathrm{MW}_{\mathrm{e}}$ range would likely become the preferred method of technology deployment. 
In this paper, the economic potential of various hybrid configurations that have been proposed for molten-salt power towers will be examined and compared to solar-only plants. The analysis will highlight the solar-specific aspects of these plants and will not blend the costs of solar energy with fossil energy. When costs are blended, identification of the preferred economic choice becomes difficult. Hybrid designs that are compatible with the needs of the huge international electricity market and provide the most environmental benefits will be identified.

\section{Market Needs for Power Towers}

The power towers analyzed herein are assumed to be exposed to insolation conditions similar to the good solar regions found in Rajasthan, India or in Egypt. Marketing studies [1] suggest that for the foreseeable future, most new power plants will be built within developing nations like India and Egypt. These countries were also selected because they represent two distinctly different power markets.

Rajasthan is currently experiencing power shortages at all times of the day and is in dire need of base-load power. Rajasthan does not have access to a naturalgas-pipeline network and future power plants are proposed to be fueled by coal, lignite, and petroleum products. In many instances, these fuels will be costly because they will be brought to plant site from great distances by train or truck.

Egypt, on the other hand, currently does not have a power shortage and has an extensive pipeline network. New natural-gas-fired power plants are under construction to meet the future power needs of the country. Furthermore, energy resources are so prevalent (gas, solar, wind) that Egypt wants to be an electricity exporter to the emerging international electricity grid. A significant demand for peak power occurs after sunset in Egypt which is currently being met with the Aswan hydroelectric project. However, the need for peaking power is increasing beyond the capabilities of Aswan and new thermal plants must be built in the near future to meet the evening peak [18].

Because of the different needs for power and the variety of fossil fuels available, the hybrid power towers analyzed herein will provide peaking power (i.e. low plant load factor) and near-base-load power (i.e. high plant load factor) and will be interfaced with fossil plants that burn natural gas or coal. In addition, since fuel prices are expected to be high in certain regions of the world, concepts with the primary purpose of saving fuel will also be examined. And finally, because certain organizations $[2,3]$ are willing to pay a premium for developing technologies that slow global warming, the cost-effectiveness of each of these solar concepts in offsetting $\mathrm{CO}_{2}$ will be assessed. 


\section{Hybrid Concepts}

From a functional point of view, there are two basic approaches to hybridizing a solar power tower to a base-load fossil plant: fuel saver and power booster. The daily power profile for each concept is depicted in Figure 2.

In a "fuel-saver" plant, fuel input to the plant is reduced when solar is available and electricity output is constant. In a Rankine cycle application, the solar steam generator can be sized to provide the entire input to the steam turbine or a fractional amount. However, when hybridizing with a base-load fossil plant, it is perhaps preferred to contribute a fractional amount of heat from solar. This keeps the fossil boiler hot all the time and prevents daily startup losses and thermal cycles. In a combined-cycle application, solar heat is added by preheating the inlet air to the gas turbine via a salt-to-air heat exchanger. Since the molten salt operating temperature is limited to less than $600^{\circ} \mathrm{C}$ and the inlet temperatures required by modern gas turbines are approaching $1400{ }^{\circ} \mathrm{C}$, the maximum amount of fuel savings that is possible (using an intercooled turbine) is approximately $27 \%$.

In a "power booster" plant, fuel input to the plant is constant and additional electricity is produced when solar heat is available. Additional electricity is produced by oversizing the steam turbine, contained within a pure Rankine cycle or the bottoming portion of a combined cycle, so that it can operate on full fossil and solar energy when solar is available. Studies of this concept have typically oversized the steam turbine from $25 \%$ to $50 \%$ beyond what the turbine can produce in the fuel-only mode. Oversizing beyond this range is not recommended because the thermal-to-electric conversion efficiency will degrade when operating in the fuel-only mode.

An advantage of a fuel-saver over a power booster plant is that a given amount of solar energy can be added to the grid for less cost because additional steam turbine capacity does not have to be built. In addition, when performing the fuel saving at the entrance to the gas turbine within a combined cycle $[4,5]$, the solar energy is converted at a higher efficiency than when adding a power boost to a pure Rankine cycle (e.g. $53 \%$ vs. $40 \%$ ).

The primary advantage of the power booster is that the economic value of the solar energy to the utility grid is greater than the fuel saver. Thus, even though the cost of adding solar energy to the grid is greater for the booster, the increased value of the solar energy more than compensates for the increased cost. In the next section it will be shown that the increased value will cause the power booster to be, in most cases, the preferred economic choice.

Simplified diagrams of hybrid power tower plants in fuel saver and power booster configurations are depicted in Figure 3. In order to compare the economics of the systems, a consistent set of conceptual designs were developed for the 
hybrid power plants. From Table 1 it can be seen that in each design a solar field was interfaced with a base-loaded combined cycle or coal-fired Rankine cycle that produces $350 \mathrm{MW}_{\mathrm{e}}$ when operating in a fossil-only mode. Power boosters with low and high plant load factors (PLF) for the solar portion (i.e. the rectangle marked "solar" in Figure 2) were developed to meet the different market needs. In all cases, the base-load portion of the hybrid plant was assumed to have an $80 \%$ PLF.

Table 2 provides the design characteristics, costs, and annual performances of the solar-only plants and the solar portion of the hybrid plants. The assumed fossil competition for each of the solar cases is also listed.

A few notes are in order regarding the data presented in Table 2:

- Heliostats are assumed to cost slightly under $\$ 100 / \mathrm{m}^{2}$. This value was obtained by reducing a recent cost estimate (given a production level of 2500 per year ([6]) for $150 \mathrm{~m}^{2}$ glass heliostats by $15 \%$ to account for construction in a developing nation [7]. The remaining costs were derived from previous studies $[8,9]$. Performance estimates were developed with the SOLERGY computer code [10]. Insolation levels were assumed to be equivalent to the Mojave Desert. Insolation similar to the Mojave can be found in the desert regions throughout the world.

- Fuel savers are shown to cost less than power boosters with the same field/receiver because a solar-specific increment to the turbine does not have to be purchased. This can be seen by comparing the installed cost listed in column 1 to column 2 and column 3 to column 4 .

- By comparing columns 1 and 2, it can be seen that for a given solar field size, more thermal storage is required for the combined cycle fuel saver than for the combined cycle power booster. This is because less peak solar thermal power can be accepted by the power block of the fuel saver than the power booster (i.e., $171 \mathrm{MW}_{\mathrm{t}}$ vs. $260 \mathrm{MW}_{\mathrm{t}}$ ) and thus more solar energy must be stored for later use.

- Since a fuel saver reduces the fuel-heat input to the power block, levelized energy costs (LEC) are expressed per unit of heat. Since a power booster adds additional electricity to the grid, LECs are expressed per unit of electricity.

- An advanced solar-only case is given to illustrate what the next step in technology development may look like beyond hybridization. 
- To allow a comparison with photovoltaic solar systems, installed costs are also expressed in units of $\$ /$ watt (peak). To convert to peak values, the effect of thermal storage must be removed. A first-order estimate can be obtained by dividing installed costs by the solar multiple, e.g. for the low PLF power booster $\$ 1.57 / \mathrm{W}=\$ 2.82 \times 10^{8} / 1 \times 10^{8} \mathrm{~W} / 1.8$.

As stated earlier, hybridization significantly reduces the cost of producing solar power relative to a solar-only design. Table 2 indicates a 20 to $25 \%$ reduction. This can be seen by comparing the levelized energy costs in column 2 to column 5 and column 3 to column 6 . There are 3 reasons for this reduction: 1) reduced capital costs for the $100 \mathrm{MW}_{\mathrm{e}}$ solar turbine because only an increment on the base-load fossil turbine must be purchased, 2) reduced O\&M costs because only an increment beyond the base-load O\&M staff and materials must be used to maintain the solar-specific part of the plant, and 3) the solar plant produces more electricity because the turbine is hot all the time and daily startup losses incurred in a solar-only plant are avoided.

The economic viability of the solar plants presented in Table 2 will be assessed in the next section.

\section{Economic Evaluation of Hybrid and Solar-Only Concepts}

In order to evaluate the economic viability of the solar plants, one must first identify the non-solar competition. Since the primary subject of this paper is hybrid solar plants, fossil fuel is assumed to be available for delivery at the site and thus a comparison with coal-fired and natural-gas-fired plants will be made. Characteristics of the fossil technologies the solar plants are assumed to offset are listed at the bottom of Table 2 and described more fully in Table 3.

For market conditions requiring a high PLF, it is assumed that the technologies being offset are either a pulverized coal Rankine cycle or a natural-gas combined cycle. Rather than constructing a hybrid plant by adding a $100 \mathrm{MW}_{\mathrm{e}}$ solar increment, the lowest-cost fossil alternative would be to add a $100 \mathrm{MW}$ fossil increment to the plant. The incremental capital and O\&M costs are listed in Table 3; capital costs associated with increasing the fossil plants from 350 to 450 $M W_{e}$ were derived from information presented in Figure 4 and incremental O\&M costs were calculated from reference [11].

For market conditions requiring a low PLF, it is assumed that a stand-alone 100 $\mathrm{MW}_{\mathrm{e}}$ gas-turbine plant will be offset by the $100 \mathrm{MW}_{\mathrm{e}}$ solar power boost to the coal or combined cycle plant. The installed cost listed in Table 3 was derived by multiplying the manufacturers list price for a $100 \mathrm{MW}$ gas turbine (Siemens V84.2) by the indirects/installation factor presented for gas turbines in reference [11]. 
After market entry is complete using the hybrid approach, large solar-only plants may be preferred. When this occurs, stand-alone combined cycle plants with ratings of $200 \mathrm{MW}$ or more could be offset. This is the reason for including the last column in Table 3.

The next step in assessing economic viability is to determine the value (i.e. the price to be paid) for the solar energy produced. This should be equal to the avoided cost of producing the equivalent energy with the fossil competition described above. Avoided costs are comprised of 3 components: capital construction, $\mathrm{O} \& \mathrm{M}$, and fuel expense.

The avoided cost of capital is typically expressed as the annualized payment needed to amortize the construction loan during a period that is equal to the life of the plant. On a levelized basis, this payment is

\section{Annual capital costs $=$ fixed charge rate ${ }^{*}$ Installed cost}

Since fixed charge rate (also called capital carrying charge) represents the fraction of capital paid per year and installed cost has units of $\$ / \mathrm{kW}$, the levelized annual capital costs (also called capacity value) has units of $\$ / \mathrm{kW}$-yr. The fixed charge rate for an investor-owned utility within the US is approximately $16 \%$ and is calculated [12] given the following economic assumptions:

- 30-yr plant life

- $10 \%$ discount rate

- $4 \%$ annual inflation

- $1 \%$ annual property insurance

- $40 \%$ tax bracket

- 15-yr depreciation life

- $1 \%$ annual property tax

The capacity values listed in Table 3 were calculated with the above equation and a $16 \%$ fixed charge rate.

The avoided cost of O\&M, on a 30-yr levelized basis, is equal to 1.5 times the O\&M cost for the first year of plant operation. The factor 1.5 converts 30 years of O\&M costs, that increase at the inflation rate, to the equivalent levelized cost given a 10\% discount rate. The O\&M costs (values) listed in Table 3 have been

\footnotetext{
${ }^{1}$ These economic assumptions do not apply to plants built in developing nations like India or Egypt... The evaluation of the appropriate economic factors for these countries is beyond the scope of this analysis. In addition, the economic model employed in this paper is admittedly simple and is only appropriate for the screening type of analysis contained herein.
} 
divided by the annual electricity produced by the fossil plant and thus have units of $\$ / \mathrm{kWh}_{\mathrm{e}}$. (The electricity produced is defined by the plant load factors listed in the table.)

The avoided cost of fuel, on a 30-yr levelized basis, is also equal to 1.5 times the first year fuel cost. Thus fuel is assumed to escalate at the inflation rate and the discount rate is assumed to be $10 \%$. Annual fuel costs (values) listed in Table 3 are a function of the plant fuel-conversion efficiencies listed in the table and have also been divided by the annual electricity. Since fuel cost is highly uncertain, fuel values are given for a variety of first-year fuel costs.

The next step in determining economic viability of the solar plants is to assign the appropriate value to the energy that the solar plants add to the grid. For a fuel saver plant it is logical to assign only the avoided cost of fuel that is saved. For a power booster plant, the value of the solar energy is increased because it not only offsets fuel but also the cost of building new power plant capacity either onsite or somewhere else on the utility grid and the O\&M associated with that new capacity. Thus, the value of energy produced by the power booster is equivalent to the full avoided cost. However, to realize this full value the power boost must meet a dispatchability requirement that is roughly equivalent to fossil plant it is offsetting. The dispatchability requirement for peaking power plants in the Mojave Desert is that they demonstrate greater than an $80 \%$ PLF from noon to $6 \mathrm{pm}$, Monday through Friday, from June through September. Studies have shown that a molten salt power tower with 6 hours of thermal storage will meet this dispatchability requirement $[13,14]$. It should be emphasized that the dispatchability requirement is totally dependent on the local power needs and must be investigated on a case by case basis. For example, because of their evening peak, Egypt might require the plant to demonstrate a high availability during the 4 hours after sunset. It is assumed here that the power boosters and solar-only plants meet the dispatchability requirement.

If the value of the solar energy is greater than the cost of producing it, economic viability is achieved. The levelized energy costs for the solar-increments and solar-only plants presented in Table 2 were calculated with the following equation:

$$
\text { LEC }=\frac{\text { Annualized Capital Costs + O\&M Costs }}{\text { Annual Energy }}
$$

As stated previously, annualized capital cost is the product of the fixed charge rate times the installed capital costs. The capital costs, 30-yr levelized O\&M costs, and annual energy are all listed in Table 2. Annual energy is either electric or thermal, depending on whether the plant is a power booster or fuel saver, respectively. Electric parasitics required to run the solar equipment have been subtracted from electric energy produced by the booster. However, 
because the product of the fuel saver is thermal energy, electric parasitics have been listed separately for this case and treated as an O\&M expense.

The economic assumptions used to calculate the fixed charge rate and the levelized energy costs for the solar cases were the same as described for the fossil competition except for the following taxation parameters:

- 5-yr depreciation life

- $0 \%$ annual property tax

- $20 \%$ investment tax credit

Recent studies indicate that if solar plants are taxed at the same rate as fossil plants, the solar plant will pay much more tax per kilowatt hour during its lifetime. Selection of the above taxation parameters have been shown to be one method of achieving tax equity between solar and fossil generated electricity for plants built in California, USA [15]. Achieving tax equity causes a very significant reduction in the fixed charge rate (reduced from 16\% to $10 \%$ ) and levelized energy cost for solar plants. In this economic analysis, it is assumed tax equity has been achieved and thus a fixed charge rate of $10 \%$ was used to calculate the solar LECs listed in Table 2.

As stated previously, economic viability occurs if value exceeds costs. If costs of producing solar energy exceeds the value, then we must justify why we are willing to pay more for solar power. Here, it was assumed that we are willing to pay more for power that produces less $\mathrm{CO}_{2}$ and quantify how much we are paying to do this. An example calculation that demonstrates the analysis methodology is presented below.

\section{Define Case}

Assess the economic viability of $100 \mathrm{MW}$ (Hi PLF) power boost to a $350 \mathrm{MW}$ base-loaded coal plant. The power boost produces $569 \mathrm{GWh} / \mathrm{yr}$ (column 3, Table 2). The coal is assumed to cost $\$ 2 / \mathrm{MBtu}$ in the first year and escalate at the inflation rate.

\section{Determine Value}

The high PLF power booster is assumed to meet the dispatchability requirement and thus qualify for the capacity, O\&M, and fuel values listed in column 1 of Table 3. The annual levelized value is calculated to be

$$
\begin{aligned}
& \text { Capacity value }=\$ 183 / \mathrm{kW}-\mathrm{yr}{ }^{*} 100,000 \mathrm{~kW}=18.3 \$ \mathrm{M} / \mathrm{yr} \\
& \text { O\&M value }=\$ 0.0078 / \mathrm{kWh}^{*} 569 \mathrm{E} 6 \mathrm{kWh}=4.4 \$ \mathrm{M} / \mathrm{yr} \\
& \text { Fuel value }=\$ 0.0296 / \mathrm{kWh}^{*} 569 \mathrm{E} 6 \mathrm{kWh}=16.8 \$ \mathrm{M} / \mathrm{yr}
\end{aligned}
$$

Total levelized value $=39.6 \$ \mathrm{M} / \mathrm{yr}$ 


\section{Determine Cost}

From column 3 of Table 2, the LEC is $\$ 0.078 / \mathrm{kWh}$. The annual levelized cost is thus

$$
\text { Total levelized cost }=\$ 0.078 / \mathrm{kWh} * 569 \mathrm{E} 6 \mathrm{kWh}=44.4 \$ \mathrm{M} / \mathrm{yr}
$$

\section{Determine Economic Viability and $\mathrm{CO}_{2}$ Avoidance Cost}

It can be seen that levelized costs exceed levelized payments by $4.8 \$ \mathrm{M} / \mathrm{yr}$. However, the solar boost avoids $5.6 \mathrm{E} 5$ tons of $\mathrm{CO}_{2} / \mathrm{yr}$ :

$$
569 \mathrm{E} 6 \mathrm{kWh} / \mathrm{yr}{ }^{*} 909 \mathrm{~g} / \mathrm{kWh}=5.2 \mathrm{E} 8 \mathrm{~kg} / \mathrm{yr}=5.6 \mathrm{E} 5 \text { tons(US) } / \mathrm{yr} \text {. }
$$

The levelized $\mathrm{CO}_{2}$ avoidance cost is thus $4.8 \$ \mathrm{M} / 5.6 \mathrm{E} 5$ tons $=\$ 8.54 /$ ton.

\section{Plot Results}

Similar calculations were performed for each of the hybrid and solar-only cases over the full range of expected fuel costs. The results of these calculations are plotted in Figure 5 (the asterisk represents the example calculation presented above.) When the avoidance cost is zero, the solar plants achieve economically viability. Major insights are annotated below:

- Cases that offset coal $(A, B, C)$ have a lower $\mathrm{CO}_{2}$ avoidance cost and have a different slope than those that offset gas $(D-I)$. There are 2 reasons for this: 1) much higher amounts of $\mathrm{CO}_{2}$ are produced by burning coal than natural gas, 2) the value of the solar energy is greater because the avoided cost of offsetting coal plants is higher than offsetting gas-fired plants (i.e., the capacity and O\&M values listed in Table 3 are higher for coal).

- The economics of case A (coal power booster) and case B (solar-only that offsets a coal increment) are superior to case $C$ (coal fuel saver). This is because in the former cases the value of solar energy is greater and equal to the full avoided cost, whereas the fuel saver only receives the value of the fuel.

- Case $E$ (combined-cycle power booster that offsets a gas-turbine plant), case $F$ (solar-only that offsets a gas-turbine plant), and case $G$ (combined-cycle fuel saver), all have the same field size but the economics of case $E$ are superior to cases $F$ and $G$, which are shown to be approximately equal. Case $E$ beats case $F$ because the LEC of case $E$ is lower than $F$, yet case $E$ receives about the same value. Case $E$ beats case $G$ because of the higher avoided cost payment that is received for the energy produced.

- The economics of case $G$ (combined-cycle fuel saver) is shown to be superior to case $\mathrm{H}$ (combined-cycle power booster that offsets a combinedcycle increment) and case I (solar-only plant that offsets a combined-cycle 
increment). The capacity and O\&M values ( $\$ 46 / \mathrm{kWyr}$ and $\$ 0.0038 / \mathrm{kWhr}$ in Table 3) received by case $H$ and $I$ are too low to compensate for the increased capital costs of these systems.

- The coal fuel-saver (C) achieves economic viability at a slightly lower fuel cost than the combined-cycle fuel saver $(G)(\$ 6.00$ vs. $\$ 6.50 / \mathrm{MBtu})$. The only reason this occurs is because case $C$ has a lower LEC due its larger solar field and improved economy of scale.

- Because of the very high fuel costs required, the economics of offsetting a combined cycle increment with current-generation power towers are unfavorable (cases $\mathrm{H}$ and I). However, the advanced solar-only case (D) shows some hope. Besides using advanced technology, Case D is improved because the solar plant is larger (200 MW vs. $100 \mathrm{MW}$ ) and is capable of offsetting an entire combined cycle plant rather than just an increment. This significantly increases the capacity and O\&M value for the electricity produced.

\section{Conclusions}

This paper has examined the economic potential of various hybrid and solar-only configurations for molten-salt power towers. The focus of the analysis was the solar-specific aspects of these plants. The value of the solar energy produced was not blended with fossil energy so that clear economic comparisons could be made.

In general, hybrid power towers were shown to be economically superior to solaronly plants with the same field size. Furthermore, the power-booster hybrid approach was generally preferred over the fuel-saver hybrid approach. The hybrid cases that showed the most promising economic potential are a power boost to a coal plant and a power boost to a combined cycle plant. However, in order for the latter case to be attractive, the solar boost must offset the construction of a new gas-turbine plant. Given the economic assumptions presented in this paper, economic viability for the coal boost occurs at a fuel cost (low heating value) of $\$ 2.60 / \mathrm{MBtu}$. Viability for the combined-cycle boost occurs at a fuel cost of $\$ 4.40 / \mathrm{MBtu}$. These fuel prices exist today in certain areas of the world (e.g. Rajasthan, India).

The cost of $\mathrm{CO}_{2}$ avoidance was also calculated for solar cases in which the fuel cost was too low for solar to be economically viable. Solar cases that offset coal plants were shown to have the lowest $\mathrm{CO}_{2}$ avoidance cost. The avoidance costs appear to be within the range of interest $(<\$ 29 /$ ton) to the Global Environmental Facility [19] who is currently providing financial support to technologies that reduce global warming. The $\mathrm{CO}_{2}$ avoidance costs also appear to be competitive with other proposed methods of removing $\mathrm{CO}_{2}$ from fossil-fired power plants and other industrial processes [20]. 


\section{References}

1. Utility Data Institute, World Directory of New Electric Power Plants, UDI2460-94, Washington, DC, March 1994.

2a. World Bank, The Solar Initiative, IEN publications clerk, G5-100, Washington, DC, March 1995.

2b. Anderson, Dennis and Kulsum Ahmed, "The Case for Solar Energy Investments", World Bank Technical Paper Number 279, ISBN 0-82133196-5, World Bank, Washington, DC, February 1995.

3. Federal Ministry for Economic Co-operation and Development (BMZ), "Concept for Development Co-operation with Asia", Bonn, Germany, 1992, contact Dr. Lotz.

4. Bechtel National Inc., Combined Cycle Solar Central Receiver Hybrid Power System, DOE/ET/21050-1, November 1979.

5. Bohn, M. S., T. A. Williams and H. W. Price, "Combined Cycle Power Tower", Solar Engineering 1995, ASME International Solar Energy Conference, March 19-24, 1995, Maui, HI.

6. Science Applications International Corp., "Heliostat Manufacturing for Near-Term Markets, Phase/Summary Report," Energy Products Division, Golden, CO, May 1996.

7. Lewis, Everett, "India's Refining Prospects Linked to Economic Growth", Oil \& Gas Journal, June 10, 1996.

8. Becker M. and P. Klimas (eds.), Second Generation Central Receiver Technologies, ISBN 3-7880-7482-5, Verlag C. F. Muller Karlsruhe, (C) 1993.

9. Letter from G. J. Kolb (Sandia) to Richard Spencer (World Bank), subject: Results of Bechtel and Sandia's study of solar-thermal-coal-hybrid plants, January 16, 1996.

10. Stoddard, M. C., et. al., SOLERGY - A Computer Code for Calculating the Annual Energy from Central Receiver Power Plants, SAND86-8060, Sandia National Laboratories, Livermore, CA, May 1987.

11. Electric Power Research Institute, TAG ${ }^{T M}$ - Technical Assistance Guide Volume 1: Electricity Supply - 1993, TR-102276-Vol. 1, Rev. 7, 1993.

12a. Doane, J. W., et al., "The Cost of Energy from Utility Owned Solar Electric Systems," ERDA/JPL 1012-76/3.

12b. Brune, J. M., BUCKS - Economic Analysis Model of Solar Electric Power Plants, Sandia National Laboratories, SAND77-8279, January 1978.

13. Chiang, C. J., SUNBURN: A Computer Code for Evaluating the Economic Viability of Hybrid Solar Central Receiver Electric Power Plants, SAND862165, Sandia National Laboratories, Albuquerque, NM, June 1987.

14. Pacific Gas \& Electric Company, Solar Central Receiver Technology Advancement for Electric Utility Applications, Phase 1 Topical Report, Report No. 007.2-88.2, San Francisco, CA, September 1988.

15. Nathan, N. H., and R. A. Chapman, Tax Equity - Solar Electric Power Plants, National Power Company, Oakland, CA, draft report prepared for Alec Jenkins at the California Energy Commission, 1994. 
16. Turbine Systems Engineering Inc., World-Wide Website http://www.gasturbines.com/TRADER/Manprice.htm, July 1996.

17. Spencer Management Associates, Integrated Solar Combined Cycle Systems (ISCCS) Using Solar Parabolic Trough Technology, Diablo, CA, October 1994.

18. . Geyer, Michael, IEA SolarPACES START Mission to Egypt, February 2329, 1996, Deutsche Forschungsanstalt fur Luft-und Raumfahrt (DLR), Draft report.

19. Personal communication with Richard Spencer, World Bank Solar Initiative, Washington, DC, November 1995.

20. Farla, J., C. Hendriks and K. Blok, "Carbon Dioxide Recovery from Industrial Processes", Conference on Climate Change, Netherlands, ISSN/ISBN: 0165-0009, April 1995.

21a. Prairie, M., J. Pacheco and G. Kolb, "Solar Central Receiver Technology: The Solar Two Project", AIChE Symposium Series 310, Vol. 92, 1996, pp. $229-233$.

21b. Chavez, J., H. Reilly, G. Kolb, B. Gould, A. Zavoico, P. Sutherland, "The Solar Two Power Tower Project: A $10 \mathrm{MW}_{\mathrm{e}}$ Power Plant", IECEC Paper Number RE-357, American Society of Mechanical Engineers, 1995. 


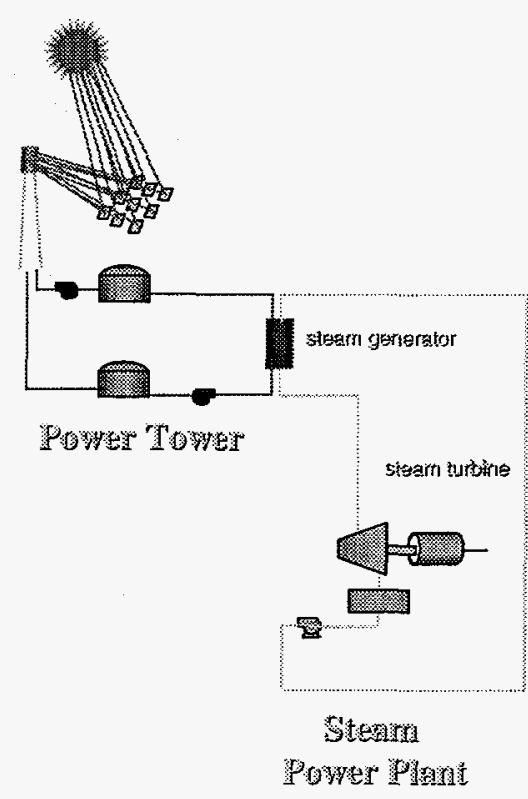

Figure $1 \quad$ Molten salt power tower in a solar-only configuration

Fuel Saver without Storage

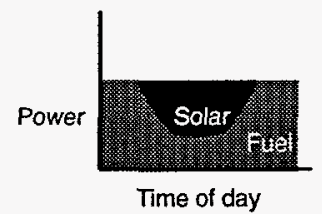

Power Booster with Storage

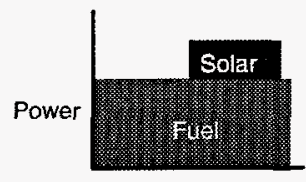

Time of day

Figure 2 Daily power profile for hybrid power tower plants. If storage were added to the fuel saver, the solar contribution would look rectangular. In the power booster profile, it can be seen that storage is used to meet an afternoon and early evening need. 


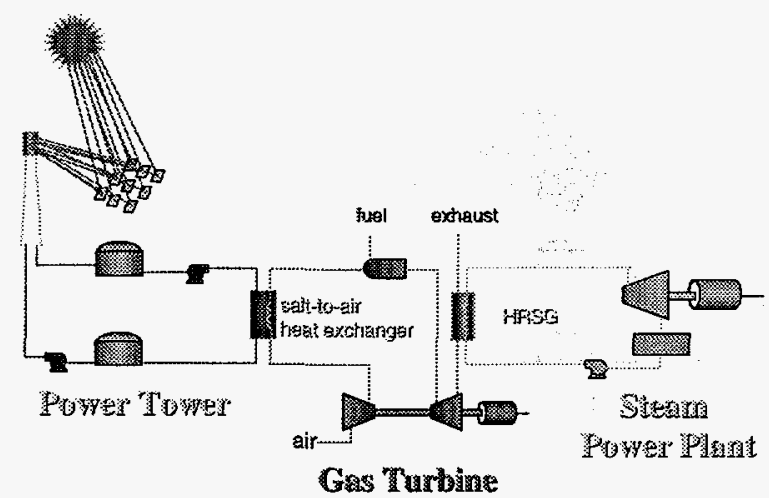

Combined-cycle fuel saver

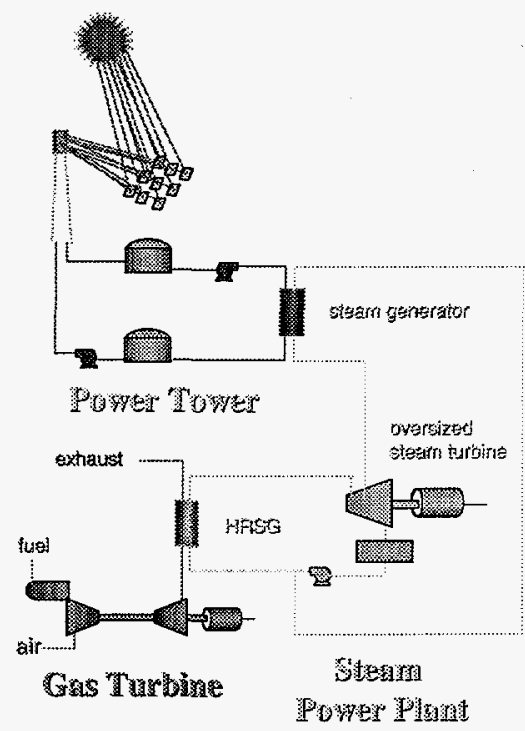

Combined-cycle power booster

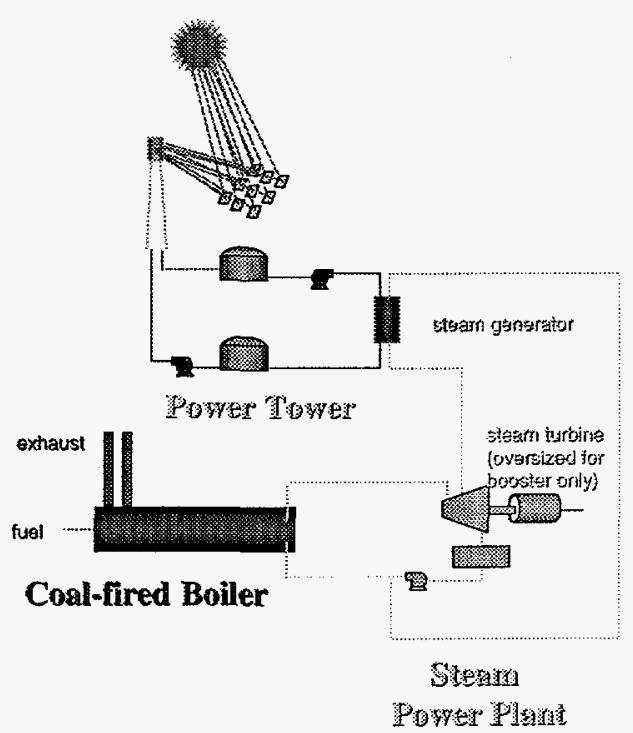

Coal power booster or fuel saver

Figure $3 \quad$ Molten salt power towers in several hybrid configurations 


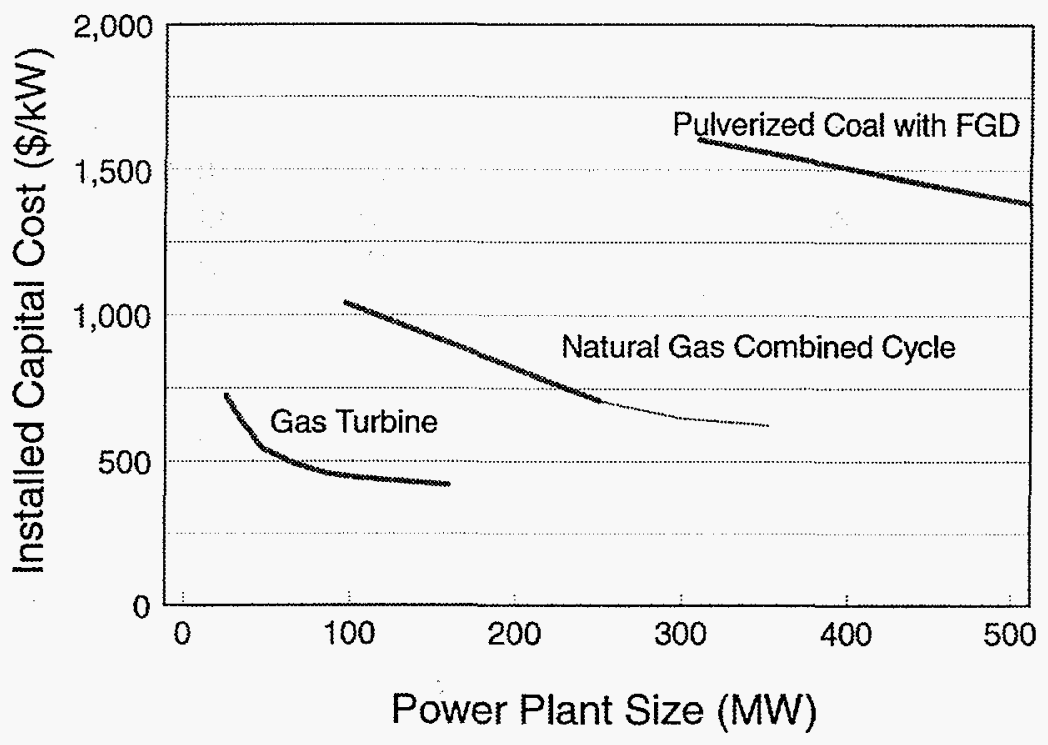

Figure 4 Installed capital costs of coal-fired [11], combined cycle [17 \& extrapolation by author], and gas turbine [11, 16] power plants

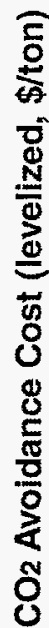

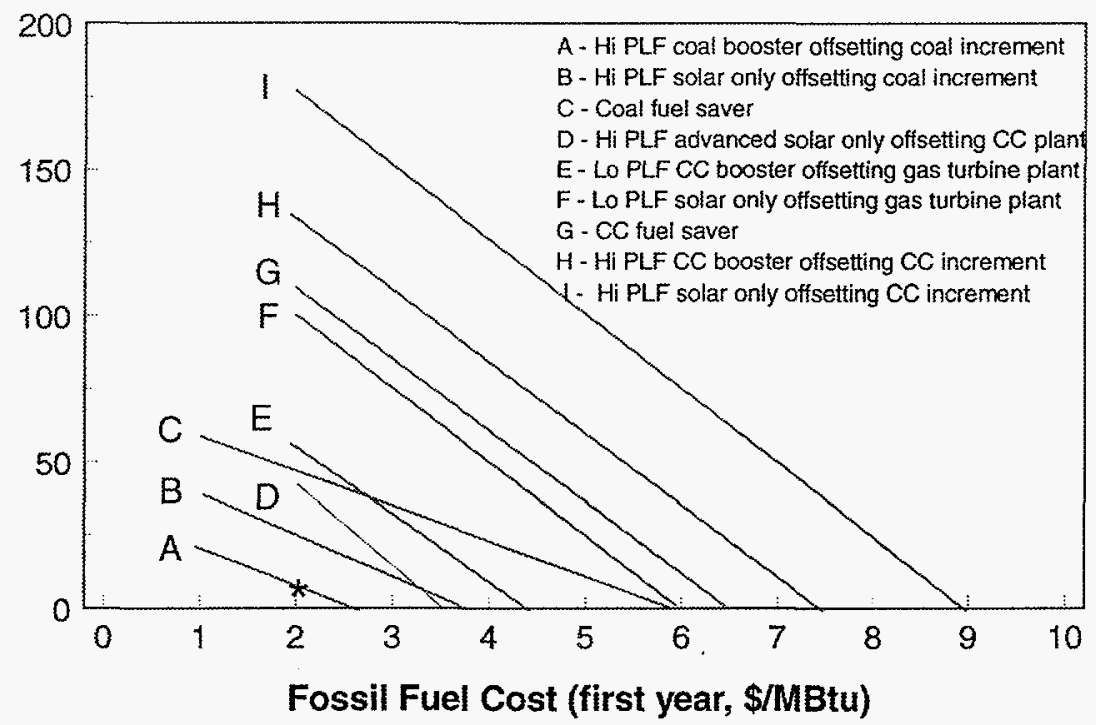

Figure 5

$\mathrm{CO}_{2}$ avoidance cost for solar options. Economic viability occurs when $\mathrm{CO}_{2}$ avoidance cost is zero. 
Table 1. Characteristics of Hybrid Power Plants

Hybrid Plant Description

$\begin{array}{llll}\text { Gas } & \text { Steam } & \text { Total } & \text { Annual } \\ \text { Turbine } & \text { Turbine } & \text { Plant } & \text { Solar } \\ \text { Power } & \text { Power } & \text { Power } & \text { Fraction } \\ \left(\mathrm{MW}_{\mathrm{e}}\right) & (\mathrm{MW}) & \left(\mathrm{MW}_{\mathrm{e}}\right) & \end{array}$

$100 \mathrm{MW}$ of Lo PLF Power Boost to a Base-loaded 350 MW Coal Plant

$\begin{array}{llll}\text { N/A } & 450 & 450 & 12.9 \% \\ \text { N/A } & 450 & 450 & 18.8 \% \\ 235 & 215 & 450 & 12.3 \% \\ 235 & 215 & 450 & 18.1 \% \\ 235 & 115 & 350 & 19.8 \% \\ & & & \\ \text { N/A } & 350 & 350 & 23.3 \%\end{array}$

$100 \mathrm{MW}$ of Hi PLF Power Boost to a Base-loaded $350 \mathrm{MW}$ Coal Plant

100 MW of Lo PLF Power Boost to a Base-loaded 350 MW CC Plant

$100 \mathrm{MW}$ of Hi PLF Power Boost to a Base-loaded 350 MW CC Plant

Fuel Saver for a $350 \mathrm{MW}$

Base-loaded CC Plant

Fuel Saver for a $350 \mathrm{MW}$

Base-loaded Coal Plant

Note:

Gas turbine is assumed to be similar to a Westinghouse 701F gas turbine with a heat rate of $9280 \mathrm{Btu} / \mathrm{kWh}(\eta=36.7 \%)$ [16]. For the combined cycle fuel saver, an intercooler is assumed to be installed (not available today for the 701F). 
Table 2. Characteristics and Costs of Solar Increment

\begin{tabular}{|c|c|c|c|c|c|c|c|}
\hline & $\begin{array}{l}\text { CC Fuel } \\
\text { Saver } \\
\text { Hybrid }\end{array}$ & $\begin{array}{l}\text { Lo PLF } \\
\text { CC or } \\
\text { Coal } \\
\text { Power } \\
\text { Booster } \\
\text { Hybrid }\end{array}$ & $\begin{array}{l}\text { Hi PLF } \\
\text { CC or } \\
\text { Coal } \\
\text { Power } \\
\text { Booster } \\
\text { Hybrid }\end{array}$ & $\begin{array}{l}\text { Coal Fuel } \\
\text { Saver } \\
\text { Hybrid }\end{array}$ & $\begin{array}{l}\text { Lo PLF } \\
\text { Solar } \\
\text { Only }\end{array}$ & $\begin{array}{l}\text { Hi PLF } \\
\text { Solar } \\
\text { Only }\end{array}$ & $\begin{array}{l}\text { Advanced } \\
\text { Solar } \\
\text { Only }\end{array}$ \\
\hline \multicolumn{8}{|l|}{ Solar Characteristics } \\
\hline & $\begin{array}{l}883000 \\
470\end{array}$ & $\begin{array}{l}883000 \\
470\end{array}$ & $\begin{array}{l}1350000 \\
715\end{array}$ & 1350000 & 883000 & 1350000 & $\begin{array}{l}2477000 \\
1400\end{array}$ \\
\hline & $\begin{array}{l}4 / 0 \\
171\end{array}$ & $\begin{array}{l}470 \\
260\end{array}$ & $\begin{array}{l}715 \\
260\end{array}$ & $\begin{array}{l}715 \\
260\end{array}$ & $\begin{array}{l}470 \\
260\end{array}$ & $\begin{array}{l}715 \\
260\end{array}$ & $\begin{array}{l}1400 \\
520\end{array}$ \\
\hline Solar Multiple & 2.7 & 1.8 & 2.7 & 2.7 & 1.8 & 2.7 & 2.7 \\
\hline Turbine Power $\left(\mathrm{MW}_{\mathrm{e}}\right)$ & --- & 100 & 100 & -- & 100 & 100 & 200 \\
\hline Storage Size (hrs) & 14 & 6 & 13 & 13 & 6 & 13 & 13 \\
\hline Storage Size $\left(M W h_{t}\right)$ & 2400 & 1600 & 3400 & 3400 & 1600 & 3400 & 6800 \\
\hline Annual Energy (GWh) & 914 th & $362 \mathrm{el}$ & $569 \mathrm{el}$ & 1472 th & $340 \mathrm{el}$ & $535 \mathrm{el}$ & $1100 \mathrm{el}$ \\
\hline Parasitics $\left(\mathrm{GWh}_{\mathrm{e}}\right)$ & 17 & -- & -- & 27 & -- & -- & -- \\
\hline \multicolumn{8}{|l|}{ Solar Specific Costs (\$M) } \\
\hline Site improvements & 6 & 6 & 8 & 8 & 6 & 8 & 10 \\
\hline Heliostats & 87 & 87 & 132 & 132 & 87 & 132 & 241 \\
\hline Receiver/Tower & 26 & 26 & 35 & 35 & 26 & 35 & 50 \\
\hline Thermal Storage & 32 & 24 & 44 & 44 & 24 & 44 & 60 \\
\hline Steam Generator & 0 & 11 & 11 & 11 & 11 & 11 & 17 \\
\hline Air Heat Exchanger & 11 & 0 & 0 & 0 & 0 & 0 & 0 \\
\hline Master Control & 1 & 1 & 1 & 1 & 3 & 3 & 3 \\
\hline Turbine & 0 & 27 & 27 & 0 & 54 & 54 & 80 \\
\hline Total Direct Costs & 163 & 182 & 258 & 231 & 211 & 287 & 461 \\
\hline Indirect Multiplier & 1.55 & 1.55 & 1.55 & 1.55 & 1.55 & 1.55 & 1.37 \\
\hline Installed Capital Costs & 253 & 282 & 400 & 358 & 327 & 445 & 632 \\
\hline Installed Cost $\left(\$ / W_{\text {peak }}\right)$ & & 1.57 & 1.48 & & 1.82 & 1.65 & 1.17 \\
\hline 1st Year O\&M Costs & 2.3 & 2.3 & 3 & 3 & 4.6 & 5.6 & 6 \\
\hline 30-yr Lev. O\&M Costs & 3.5 & 3.5 & 4.5 & 4.5 & 6.9 & 8.4 & 9 \\
\hline \multicolumn{8}{|l|}{$\begin{array}{l}\text { Levelized Energy Cost } \\
\text { Fuel Savers (\$/MBtu) }\end{array}$} \\
\hline Capital & 8.0 & & & 7.1 & & & \\
\hline O\&M & 1.1 & & & 0.9 & & & \\
\hline Parasitics & 0.4 & & & 0.4 & & & \\
\hline Total & 9.5 & & & 8.4 & & & \\
\hline \multicolumn{8}{|l|}{$\begin{array}{l}\text { Power Boosters and } \\
\text { Solar Only }\left(\$ / k W h_{e}\right)\end{array}$} \\
\hline Capital & & 0.078 & 0.070 & & 0.097 & 0.082 & 0.057 \\
\hline O\&M & & 0.009 & 0.008 & & 0.020 & 0.016 & 0.008 \\
\hline Total & & 0.087 & 0.078 & & 0.117 & 0.098 & 0.065 \\
\hline Fossil Competition & $\begin{array}{l}\text { Natural } \\
\text { Gas } \\
\text { Fuel }\end{array}$ & $\begin{array}{l}\text { Gas } \\
\text { Turbine } \\
\text { Plant }\end{array}$ & $\begin{array}{l}\text { Increment } \\
\text { to CC or } \\
\text { Coal Plant }\end{array}$ & $\begin{array}{l}\text { Coal } \\
\text { Fuel }\end{array}$ & $\begin{array}{l}\text { Gas } \\
\text { Turbine } \\
\text { Plant }\end{array}$ & $\begin{array}{l}\text { Increment } \\
\text { to CC or } \\
\text { Coal Plan }\end{array}$ & $\begin{array}{l}\text { Combined } \\
\text { Cycle } \\
\text { t Plant }\end{array}$ \\
\hline
\end{tabular}

Notes

* The annual energies shown are applicable to a power boost on a coal plant. These energies should be reduced by $5 \%$ for a power boost on a combined cycle plant due to the lower Rankine efficiency.

** Solar multiple is the ratio of the above 2 rows. Excess energy produced by the receiver is sent to the thermal storage tank for later use.

*** This is a 30-yr "current" dollar estimate which includes the effects of inflation. See paper for explanation of economic assumptions. 
Table 3. Characteristics of Fossil Technologies Being Offset by Solar Power Towers

\begin{tabular}{|c|c|c|c|c|}
\hline & $\begin{array}{l}\text { Incremental } \\
\text { Pulverized Coal }\end{array}$ & $\begin{array}{l}\text { Incremental } \\
\text { Combined Cycle }\end{array}$ & $\begin{array}{l}\text { Stand-Alone } \\
\text { Gas Turbine }\end{array}$ & $\begin{array}{l}\text { Stand-Alone } \\
\text { Combined } \\
\text { Cycle }\end{array}$ \\
\hline & with FGD & Natural Gas & & Natural Gas \\
\hline $\begin{array}{l}\text { Type and Size } \\
\text { of Fossil Addition }\end{array}$ & $\begin{array}{l}100 \mathrm{MW} \\
\text { increment } \\
\text { between } \\
350 \text { and } 450 \mathrm{MW}\end{array}$ & $\begin{array}{l}100 \mathrm{MW} \\
\text { increment } \\
\text { between } \\
350 \text { and } 450 \mathrm{MW}\end{array}$ & $\begin{array}{l}100 \mathrm{MW} \\
\text { stand alone } \\
\text { power plant }\end{array}$ & $\begin{array}{l}200 \mathrm{MW} \\
\text { stand alone } \\
\text { power plant }\end{array}$ \\
\hline Installed Cost $\left(\$ / \mathrm{kW}_{\mathrm{e}}\right)$ & 1140 & 290 & 410 & 800 \\
\hline $\begin{array}{l}\text { 1st yr O\&M Cost }\left(\$ / k W h_{e}\right) \\
\text { 30-yr Lev. O\&M Cost }\end{array}$ & $\begin{array}{l}0.0052 \\
0.0078\end{array}$ & $\begin{array}{l}0.0025 \\
0.0038\end{array}$ & $\begin{array}{l}0.0040 \\
0.0060\end{array}$ & $\begin{array}{l}0.0030 \\
0.0045\end{array}$ \\
\hline $\begin{array}{l}\text { Fossil Plant } \\
\text { Net Efficiency (Annual,LHV) }\end{array}$ & $35 \%$ & $53 \%$ & $33 \%$ & $53 \%$ \\
\hline Plant Load Factor & $80 \%$ & $80 \%$ & $40 \%$ & $80 \%$ \\
\hline $\mathrm{CO}_{2}$ Emissions $\left(\mathrm{g} / \mathrm{kWh} \mathrm{h}_{\mathrm{e}}\right)$ & 909 & 345 & 554 & 345 \\
\hline Capacity Value $\left(\$ / \mathrm{kW}_{\mathrm{e}}-\mathrm{yr}\right)^{*}$ & 183 & 46 & 66 & 128 \\
\hline O\&M Value $\left(\$ / k W h_{\mathrm{e}}\right)^{*}$ & 0.0078 & 0.0038 & 0.006 & 0.0045 \\
\hline $\begin{array}{l}\text { Fuel Value }\left(\$ / \mathrm{kWh}_{\mathrm{e}}\right)^{*} \\
\text { Given 1st yr fuel cost (LHV) }\end{array}$ & & & & \\
\hline $1 \$ /$ MBtu & 0.0148 & --- & ---- & -..- \\
\hline $2 \$ / M B t u$ & 0.0296 & 0.0193 & 0.0310 & 0.0193 \\
\hline $3 \$ / M B t u$ & 0.0444 & 0.0290 & 0.0465 & 0.0290 \\
\hline $4 \$ / M B t u$ & 0.0592 & 0.0386 & 0.0620 & 0.0386 \\
\hline $5 \$ / M B t u$ & $\cdots$ & 0.0483 & 0.0775 & 0.0483 \\
\hline $6 \$ / M B t u$ &.-- & 0.0579 & 0.0931 & 0.0579 \\
\hline
\end{tabular}

Notes:

* These are 30-year levelized values. See paper for explanation of economic assumptions.

** LHV - Low Heating Value for fuel 